\title{
PEREMPUAN DAN ISU POLIGAMI DI INDONESIA
}

\author{
Lina Kushidayati \\ Institut Agama Islam Negeri (IAIN) Kudus \\ linakushidayati@gmail.com
}

\begin{abstract}
s
This article describes the contributions given by Indonesia women to the family laws, especially the issue of polygyny/polygamy. This is a historical research aims at providing a balance perspective on women responses upon the enactment of Islamic family law in Indonesia. Despite the socio political condition which limited women's role in public, Indonesian women were actively contributed to the debate concerning family law issues, such as polygamy. Arguments given by female scholars and activist could not be separated from their socio political background. This is a historical research aims at understanding the role of Indonesia women in negotiating polygamy in public sphere and their ways of promoting their views and opinions. Data are collected through library research and then analyzed in order to find the pattern of argumentation and contribution given by women in polygyny issues.
\end{abstract}

Key words: women, polygamy, historical

\section{Pendahuluan}

Indonesia dipandang sebagai salah satu Negara Muslim yang mengakomodasi nilai-nilai kesetaraan jender dalam peraturan perundang-undangan. Undang-Undang No. 1 Tahun 1974 tentang Perkawinan, Inpres No 1 Tahun 1991 tentang Kompilasi Hukum Islam, Undang-undang No 7 Tahun 1989 tentang Peradilan Agama sering dijadikan sebagai bukti bagaimana legalisasi hukum keluarga Islam di Indonesia berjalan seiring dengan upaya penyetaraan kedudukan antara laki-laki dan perempuan, terutama dalam bidang hukum. UU Perkawinan, dan peraturan terkait lainnya, memberikan status sosial yang sama bagi laki-laki dan perempuan serta hak yang sama untuk mengajukan perceraian di depan pengadilan. Selain itu, UU Perkawinan juga menghendaki adanya persetujuan istri bagi suami yang hendak menikah lagi (poligami). Selain itu ada syarat-syarat yang harus dipenuhi oleh suami untuk dapat terkabulnya permohonan poligami. 
UU Perkawinan bukan sekedar mengatur perkawinan secara administratif semata, melainkan merupakan sebuah peraturan yang mengandung nilai religious di dalamnya. Hal ini bisa dilihat dari isi UU Perkawinan yang menekankan pentingnya agama dalam sebuah ikatan perkawinan, mulai dari definisi perkawinan sebagai "ikatan lahir batin antara seorang pria dan seorang wanita sebagai suami istri dengan tujuan membentuk keluarga atau rumah tangga yang bahagia dan kekal berdasarkan Ketuhanan Yang Maha Esa” (Pasal 1) hingga adanya aturan bahwa perkawinan harus dilakukan menurut hukum agama masing-masing mempelai (Pasal 2 ayat (1)). Nuansa religious dalam UU Perkawinan pada dasarnya bertujuan untuk mengakomodasi keinginan umat Islam yang sebelumnya menentang UU perkawinan(Katz and Katz 2016). Selain itu, UU Perkawinan juga dianggap sebagai hasil perjuangan pergerakan perempuan di Indonesia dalam mendapatkan posisi yang setara dengan laki-laki (Blackburn 2004; Martyn 2005)(Blackburn 2004).

Sementara itu, Kompilasi Hukum Islam (KHI) dan UU Peradilan Agama, selaras dengan UU Perkawinan, juga memberikan jaminan kesetaraan hak bagi perempuan di dalam hukum, diantaranya dalam hal perceraian dan waris. UU Peradilan Agama member kesempatan yang sama bagi perempuan dan laki-laki untuk mengajukan perkara ke pengadilan, baik dalam hal perkawinan, perceraian, maupun waris. KHI adalah produk dari rasionalisasi hukum yang merubah bentuk dari fiqh yang bersifat terbuka dan arbitrer menjadi bentuk hukum yang baku (Nurlaelawati, 2010). Peradilan agama sendiri sebelum lahir UU No. 7 Tahun 1989 sudah ditegaskan keberadaanya dalam dalam UU No. 1 Tahun 1974 tentang Perkawinan. Dalam pasal 63 termuat bahwa yang dimaksud dengan pengadilan dalam UU ini adalah Pengadilan Agama bagi yang beragam Islam dan Pengadilan Umum bagi yang lain.

Peraturan perundang-undangan tentang perkawinan di Indonesia, jika dilihat dari aspek sejarah, baik pada masa kolonial maupun setelah proklamasi kemerdekaan selalu memiliki keterkaitan dengan kepentingan pemerintah. Pada masa pemerintah Belanda, sistem hukum yang mengatur tentang Perkawinan terbagi menjadi tiga berdasarkan penggolongan penduduk. Golongan pertama adalah orang Eropa dan mereka yang dipersamakan statusnya dengan orang Eropa (Jepang dan Cina). Selanjutnya peraturan kedua Staatsblad 1933 no. 74 yang berlaku bagi orang Indonesia yang beragama Kristen. Sedangkan bagi orang Islam serta Timur Asing lainnya, berlaku hukum agama atau hukum adat maisng-masing (Bedner and Huis, 2010). Penggolongan tersebut berkaitan dengan kebijakan pemerintah kolonial bagi masing- 
masing individu apakah termasuk penduduk pribumi atau Eropa (O’Shaughnessy, 2006).

Pluralitas hukum perkawinan juga masih dipertahankan oleh pemerintah Indonesia setelah Proklamasi Kemerdekaan. Pemerintah merasa perlu untuk mempunyai ketentuan pencatatan nikah, talak dan ruju'. Karena itu dikeluarkan UU No. 22 Tahun 1946. Untuk sementara UU itu hanya berlaku untuk wilayah Jawa dan Madura (Azizy, 2002). Sejak proklamasi kemerdekaan, pemerintah Republik Indonesia berusaha untuk melakukan unifikasi peraturan perundang-undangan dalam bidang perkawinan. Akan tetapi karena sifatnya yang sangat sensitif dan berkaitan erat dengan aspek spiritual dan kebudayaan, maka usaha unifikasi tersebut bukanlah hal yang mudah dilakukan(Rasjidi, 1991). Hingga akhirnya pada akhir 1950, pemerintah membentuk Panitia Penyelidik Peraturan dan Hukum Perkawinan, Talak dan Rujuk bagi umat Islam. Pembentukan tersebut dituangkan dalam Surat Perintah Menteri Agama No. B/2/4299 tertanggal 1 Oktober 1950 (Sosroatmodjo and Aulawi, 1978). Panitia tersebut bertugas untuk menyusun naskah Rancangan Undang-Undang Perkawinan yang bisa diberlakukan bagi segenap kalangan dan mampu menampung keanekaragaman praktek hukum perkawinan yang berlaku pada masa itu. Tim yang diketuai oleh Tengku Hasan tersebut beranggotakan ahli hukum umum, ahli hukum Islam dan Kristen (Nani Suwondo, 1981).

\section{Negara, Agama dan Jender}

Kajian tentang Negara, agama dan jender sudah banyak dilakukan oleh peneliti dengan pendekatan yang bervariasi. Susan Blackburn mengkaji tentang representasi perempuan dalam dunia politik di Asia Tenggara utamanya di partai politik dan di parlemen (Susan Blackburn, 1991). Sementara itu William Liddle dan Adrian Vickers lebih memfokuskan kajian pada peran militer, partai politik dan oposisi serta perkembangan ekonomi di masa Orde Baru (Liddle, 1996). Dalam bukunya yang lain Susan Blackburn menunjukkan bahwa kebijakan pemerintah Orde Baru terhadap perempuan seringkali tidak sesuai dengan harapan, dan perempuan juga rawan menjadi korban diskriminasi (Blackburn, 2004). Kajian Elizabeth Martyn difokuskan pada gerakan perempuan tahun 1950 an yang menunjukkan bahwa gerakan jender seringkali tidak mendapat perhatian dari pemerintah (Martyn, 2005).

Linda Rae Bennet yang melakukan kajian tentang perspektif perempuan single tentang seksualitas memaparkan bahwa control atas seksualitas perempuan selalu menjadi perhatian utama baik oleh 
Negara, Islam maupun adat (Bennett, 2005). Masih terkait dengan perspektif perempuan tetang hukum keluarga. Nina Nurmila menelaah tentang perspektif serta pengalaman perempuan terkait poligami. Kajian ini dilakukan ditengah minimnya data tentang perspektif perempuan pelaku tentang poligami (Nurmila, 2009).

Pendekatan hukum dan atropologi adalah metode yang dipergunakan oleh Euis Nurlaeawati dan John R. Bowen. Euis Nurlaelawati mengkaji tentang penerapan KHI sebagai peraturan hukum yang sudah dikodifikasi serta memiliki otoritas hukum. Penelitian ini utamanya fokus pada praktek yang terjadi diantara hakim di pengadilan agama dalam menerapkan KHI (Nurlaelawati, 2010). John R. Bowen lebih tertarik untuk menganalisa wacana yang berkembang di masyarakat untuk menjawab pertanyaan tentang nilainilai kesetaraan dalam agama dan hukum dalam sebuah masyarakat yang plural. Menurut Bowen, masyarakat merupakan pihak aktif dalam tarik-menarik antara adat, Negara dan Islam (Bowen, 2003). Penelitian yang menarik dilakukan oleh Kate Elizabeth O'Shaughnessy yeng mengkaji dampak UU perkawinan pada posisi perempuan. Penelitian yang dlakukan tidak hanya melihat dampak dari UU perkawinan akan tetapi mencakup hukum keluarga nasional serta pengaruhnya dalam usaha perempuan untuk menegosiasikan kedudukan mereka (O’Shaughnessy, 2006).

Dalam penelitian ini ada beberapa konsep yang penting untuk ditekankan. Konsep tentang Negara mempunyai makna yang penting dalam penelitian ini. Indonesia pada dasarnya pernah memiliki beberapa bentuk Negara yang berbeda yang tentu saja juga memiliki kebijakan hukum tentang perempuan yang berbeda-beda. Oleh karena itu penting untuk mendalami bagaimana kebijakan hukum pada masa pemerintah kolonial, pasca-kolonial serta pasca reformasi. Dalam penelitian ini yang dimaksud dengan Negara adalah ideologi kekuasaan yang dimiliki dan diterapkan oleh penguasa pada masanya masingmasing. Yang perlu diperhatikan bahwa Negara tidak pernah menjadi konsep lengkap serta bukan pula semata-mata kekuasaan atas manusia, karena Negara akan selalu dibentuk dan dibentuk lagi oleh manusia sebagai agen (Day, 2002).

Konsep bangsa sebagai imagined community yang dikemukakan oleh Benedict Anderson (Anderson, 1991) akan membantu memahami Indonesia sebagai sebuah bangsa yang plural. Perubahan kebijakan pemerintah tentang siapakah orang Indonesia, yang terkadang memasukkan dan mengeluarkan etnis tertentu dari konsep bangsa "Indonesia" diharapkan mampu menjelaskan posisi perempuan dalam diskurkus bangsa. 


\section{Perempuan dan Hukum Perkawinan Periode Kemerdekaan}

Timbulnya pergerakan wanita merupakan realisasi dari cita-cita Kartini yang memperjuangkan perbaikan kedudukan sosial wanita. Pergerakan wanita awal abad ke-20 identik dengan pergerakan pada wilayah sosial dan pendidikan. Mereka lebih banyak bergerak pada perbaikan kedudukan sosial dan peningkatan kecakapan melalui pendidikan maupun keterampilan serta perbaikan dalam hidup keluarga, perkawinan dan mempertinggi kecakapan sebagai seorang ibu (Pranoto, 1994).

Urusan politik belum menjadi konsentrasi utama pergerakan wanita awal abad ke-20. Setelah tahun 1920 organisasi wanita semakin luas orientasinya terutama dalam menjangkau masyarakat bawah dan tujuan politik dilakukan bersama-sama organisasi sosial dan politik pada umumnya. Keterlibatan kaum wanita pada masa pergerakan nasional dimulai dengan keberadaaan bagian wanita di organisasiorganisasi induk seperti Puteri Mardika yang merupakan organisasi keputrian di Budi Utomo. Sebagai bagian dari organisasi induk tentu jalan pergerakan wanita harus mengikuti organisasi induk tersebut. Semakin meningkatnya perjuangan nasional dan timbulnya berbagai perkumpulan atau organisasi, maka berdiri pula perkumpulanperkumpulan wanita.

Paham kebangsaan dan persatuan Indonesia berkembang dalam beberapa jenis organisasi wanita tersebut oleh karenanya guna membulatkan tekad dan mendukung persatuan Indonesia diadakan Kongres Perempuan Indonesia di Yogyakarta sebagai manifestasi dari kesadaran nasional kaum wanita. Kongres Perempuan Indonesia Pertama ini dilaksanakan pada tanggal 22-25 Desember 1928 yang bertujuan mempersatukan cita-cita dan memajukan wanita Indonesia serta membuat gabungan organisasi wanita. Kongres tersebut dihadiri kurang lebih 30 perkumpulan wanita. Kongres Perempuan Indonesia yang pertama ini dipimpin oleh R.A. Soekonto sebagai ketua, St. Mundjiah sebagai wakil ketua, Siti Sukaptinah sebagai sekertaris I, Sunaryati sebagai sekertaris II dan R.A Harjodiningrat sebagai bendahara (Proyek Penelitian dan Pencatatan Kebudayaan Daerah 1977).

Diantara kesepakatan yang dihasilkan adalah kongres berkeputusan untuk mencegah perkawinan anak-anak dengan cara tiap anggota harus membuat propaganda tentang buruknya perkawinan anak-anak dan minta tolong kepada pegawai Pamong Praja supaya memberi penerangan kepada rakyat tentang hal ini. 
Diantara perkumpulan perempuan yang memperjuangkan kedudukan perempuan di Indonesia adalah Isteri Sedar yang didirikan tanggal 22 Maret 1930 di Bandung yang diketuai oleh Soewarni Djojosapoetro. Isteri Sedar bertujuan untuk menginsyafkan perempuan akan harga dirinya sendiri dengan cara, diantaranya: "memerangi keadaan-keadaan social yang merendahkan derajat kaum perempuan Indonesia, seperti: kesukaran pencaharian hidup, perbedaan upah antara perempuan dna laki-laki, buta huruf, kekurangan kesempatan pendidikan bagi anak perempuan, permaduan, kawin paksaan, perkawinan anak-anak, perceraian yang tidak adil dan lain-lain" (Hamdani, 1984).

Perjuangan melawan ketidakadilan pada perempuan dalam perkawinan, termasuk poligami, juga dilakukan oleh perempuan Muslim di Indonesia. Terbukti dengan keikutsertaan organisasi perempuan Muslim, Aisyiyah dan Jong Islammieten Bond Dames Afdeling (JIBDA) dalam Kongres Perempuan Indonesia I. Polemik timbul ketika membahas tentang kedudukan wanita dalam perkawinan. Ajaran Islam, diantaranya yang memperbolehkan poligami, diserang karena dianggap tidak memberikan kedudukan yang setara bagi lakilaki dan perempuan. Akibatnya perdebatan bergeser dari persoalan kedudukan perempuan menjadi perdebatan agama (Mangkusasmito and Issom, 1984).

Kongres Perempuan Indonesia Ketiga (KPI III) diadakan di Bandung pada tanggal 23-27 Juli 1938. Kongres ini dipimpin oleh Emma Poeradiredja, Ketua Pasundan Istri Bandung. Adapun asas dan tujuannya sama dengan KPI II. Asas-asas kemudian dipertegas lagi dengan ditambahkan bahwa untuk menjalankan kewajiban sebagai Ibu Bangsa maka KPI harus menuntut persamaan hak dan harga antara laki-laki dan wanita, persamaan harus didasarkan pada kodrat dan kewajiban masing-masing. Pada kongres ini juga disusun Rancangan Undang-Undang perkawinan berdasarkan agama Islam (Panitia Peringatan 30 Tahun Kesatuan Pergerakan Wanita 1958).

Usaha Pembentukan undang-undang perkawinan di Indonesia dimulai sejak tahun 1950. Pada waktu itu, pemeritah membentuk panitia penyelidikan peraturan hukum perkawinan, talak, dan rujuk yang memiliki tugas:

1. Melakukan pembahasan mengenai berbagai peraturan perkawian yang telah ada; dan

2. Menyusun rancangan undang-undang (RUU) perkawinan yang sesuai dengan dinamika dan perkembangan zaman.

Tugas yang kedua merupakan tugas pokok, sedangkan tugas yang pertama merupakan tugas antara. 
Terbentuknya tim penyusunan RUU Perkawinan tidak lepas dari desakan beberapa pihak termasuk Front Wanita dalam Parlemen yang beranggotakan semua anggota perempuan di DPR. Bulan Agustus 1950 terbentuklah "Panitia Penyelidik Peraturan Hukum Perkawinan, Talak dan rujuk" yang diketuai Mr. Tengku Hasan. Diantara anggota panitia ini adalah : Mr. Maria Ulfah, Mr. Tuti Harahap, Mr. Nani Soewondo, Ibu Mahmudah Mawardi, Ibu Arudji Kartawinata, Ibu Pudjotomo, dan Ibu Kwari Sosrosumarto (Nani Suwondo, 1984).

Seiring dengan usaha merancang RUU perkawinan, Panitia NTR juga mengajukan keberatan kepada pemerintah terkait PP 19 tahun 1952 yang memungkinkan laki-laki menunjuk lebih dari seorang isteri sebagai penerima pension. PP ini disinyalir akan meningkatkan angka poligami di kalangan pegawai negeri. Karena tidak mendapatkan respon dari pemerintah, setelah beberapa kali mengajukan keberatan, akhirnya tanggal 17 Desember1953, Perwari mengadakan demonstrasi serentak di seluruh Indonesia menuntut dua hal:

1. Supaya pemerintah mengeluarkan RUU perkawinan yang menjamin kedudukan hokum bagi perempuan

2. Membekukan PP No 19 tahun 1952 (Nani Suwondo, 1984)

Menurut Nani Suwondo, Fatmawati Soekarno sebagai Ibu Negara bersama dengan Presiden Soekarno menerima perwakilan demonstran. Pada saat itu Fatmawati mempertanyakan alasan Perwari melakukan demonstrasi sementara perempuan Indonesia menurutnya sudah memiliki kedudukan yang lebih baik. Akan tetapi beberapa waktu kemudian, setelah Presiden Soekarno menikahi Hartini, Fatmawati berbalik mempertanyakan peran Perwari dalam memperjuangkan kedudukan perempuan (Nani Suwondo, 1984).

Empat tahun kemudian (1954), panitia telah berhasil menyusun dua RUU perkawinan: pertama,RUU perkawinan yang bersifat umum yang diselesaikan pada tahun 1952; dan kedua, RUU perkawinan khusus bagi umat islam yang diselesaikan pada tahun 1954. Selama (1958-1959), Dewan Perwakilan Rakyat telah membahas dua rancangan tersebut. Akan tetapi dua RUU tersebut tidak berhasil lolos menjadi undang-undang.

RUU Perkawinan, diajukan kembali ke parlemen tahun 1958. Saat itu RUU Perkawinan Islam bersaing dengan RUU Perkawinan baru yang mencakup semua warga negara, tanpa memandang agamanya. RUU baru ini dsebut 'RUU Ny.Sumari'. Disebut demikian karena pengajuan RUU ini dipimpin oleh Ny.Sumari dari PNI. RUU inilah yang bersaing dengan RUU Perkawinan Islam 1954 (yang telah direvisi). Pembahasan RUU yang dimulai awal 1959 ini berlangsung sengit di Parlemen. Aktivis perempuan, Nani Soewondo, menyebutkan 
bahwa partai-partai Islam membela poligami, seakan-akan poligami adalah hal yang prinsip dari sebuah pernikahan. Bagi kubu partai Islam, persoalannya pembelaan poligami tak sekedar hal yang dibolehkan agama, tetapi lebih merupakan simbol pergulatan ideologis antara kubu Islam dan sekuler. Sebaliknya, Mujiburrahman dalam disertasinya di Leiden mengenai hubungan Islam dan Kristen di Indonesia, menyebutkan pendapat Zaini Ahmad Noeh, bekas Pejabat Departemen Agama. Zaini Ahmad Noeh mengatakan RUU Ny.Sumari tidak menyebutkan sedikitpun Peradilan Islam atau Hakim Islam, tetapi hanya peradilan sipil. Artinya RUU Ny. Sumari ini akan meniadakan peradilan Islam dalam persoalan perkawinan dalam Islam (Mujiburrahman, 2006).

\section{UU Perkawinan No 1 tahun 1974 dan Poligami}

Pada tahun 1966, Menteri Kehakiman menugaskan Lembaga Pembinaan Hukum Nasional untuk menyusun RUU perkawinan yang bersifat nasional. Pada tahun 1967, pemerintah menyampaikan RUU khusus untuk umat islam kepada DPR (sebagai hasil kerja dari LPHN); dan pada tahun 1968,pemerintah mengajukan RUU tentang ketentuanketentuan pokok perkawinan kepada DPR. Akan tetapi, dua RUU ini pun tidak lolos menjadi undang-undang.

Simposium Ikatan Sarjana Wanita Indonesia (ISWI) pada tanggal 1972 menyarankan agar supaya PP ISWI memperjuangkan tentang Undang-Undang Perkawinan. Kemudian Badan Musyawarah Organisasi-Organisasi Wanita Islam Indonesia pada tanggal 22 Februari 1972 salah satunya menghasilkan keputusan untuk mendesak pemerintah agar mengajukan kembali RUU tentang Pokok-Pokok Perkawinan Umat Islam dan RUU tentang Ketentuan Pokok-Pokok Perkawinan. Tuntutan yang kedua dari Organisasi Islam Wanita Indonesia adalah menyarankan kepada segenap anggota DPR RI hasil Pemilu agar menempuh segala cara yang dimungkinkan oleh peraturan tata tertib DPR RI untuk melahirkan kedua RUU perkawinan yang diajukan pemerintah (Sosroatmodjo and Aulawi, 1978).

Pada tanggal 31 juli 1973, presiden menyampaikan RUU tentang perkawinan kepada DPR dan menarik kembali dua RUU yang sudah diajukan sebelumnya. RUU yang diajukan kepada DPR pada tahun 1973 inilah yang kemudian menjadi undang-undang perkawinan.

Menurut Pasal 1 undang-undang Nomor 1 tahun 1974, perkawinan adalah ikatan lahir batin antara seorang pria dengan seoran wanita sebagai suami isteri untuk membentuk keluarga (rumah tangga) yang bahagia dan kekal berdasarkan Ketuhanan Yang Maha Esa. Dari perumusan tersebut jelas bahwa arti perrkawinan adalah "ikatan lahir 
batin antara seorang pria dengan seorang wanita sebagai suami isteri", sedangkan tujuannya adalah "membentuk keluarga (rumah tangga) yang bahagia dan kekal berdasarkan Ketuhanan Yang Maha Esa". Dengan perkataan ikatan lahir batin tersebut dimaksudkan bahwa hubungan suami isteri tidak boleh semata-mata hanya berupa ikatan lahiriah saja dalam makna seorang pria dan wanita hidup bersama sebagai suami isteri dalam ikatan formal, tetapi juga kedua-duanya harus membina ikatan batin. Tanpa ikatan batin, ikatan lahir mudah sekali terlepas. Jalinan ikatan lahir dan ikatan batin itulah yang menjadi pondasi yang kokoh dalam membina keluarga yang bahagia dan kekal.

Rumah tangga yang dibentuk haruslah didasarkan pada Ketuhanan Yang Maha Esa. Hal ini berarti bahwa norma-norma (hukum) agama harus menjiwai perkawinan dan pembentukan keluarga yang bersangkutan. Oleh karena itu, jelaslah bahwa perkawinan menurut Undang-Undang Nomor 1 Tahun 1974 tidak semata-mata hubungan hukum saja antara seorang pria dengan seorang wanita, tetapi juga mengandung aspek-aspek lainnya seperti agama, biologis, sosial, dan adat istiadat. Agar tujuan tercapai, maka setelah terjadinya perkawinan harus ada keseimbangan kedudukan antara suami isteri. Dengan demikian, segala sesuatu yang terjadi dalam keluarga merupakan hasil putusan bersama antara suami isteri berdasarkan hasil perundingan yang didasari oleh sifat musyawarah.

Pengertian perkawinan menurut Undang-Undang Nomor 1 Tahun 1974, didasarkan pada unsur agama/religius, hal itu sebagaimana diatur di dalam Pasal 1 yaitu perkawinan adalah ikatan lahir batin antara seorang pria dengan seorang wanita sebagai suami isteri dengan tujuan membentuk keluarga (rumah tangga) yang bahagia dan kekal berdasarkan Ketuhanan Yang Maha Esa". Pada pengertian tersebut, terkandung unsur-unsur sebagai berikut:

1) Ikatan lahir dan batin.

Ikatan lahir dan batin adalah bahwa ikatan itu tidak cukup dengan ikatan lahir ataupun ikatan batin saja tetapi keduanya harus terpadu erat. Ikatan lahir merupakan ikatan yang dapat dilihat dan mengungkapkan adanya hubungan hukum antara seorang pria dan seorang wanita untuk hidup sebagai suami isteri yang disebut sebagai hubungan formal. Sedangkan ikatan batin merupakan hubungan yang tidak formal, suatu ikatan yang tampak tidak nyata yang hanya dapat dirasakan oleh pihak-pihak yang bersangkutan. Ikatan batin merupakan dasar ikatan lahir yang dapat dijadikan sebagai pondasi dalam membentuk dan membina keluarga yang bahagia.

2) Antara seorang pria dan seorang wanita. 
Ikatan perkawinan hanya boleh dan mungkin terjadi antara seorang pria dan seorang wanita. Dalam hal ini juga terkandung asas monogami yaitu pada saat yang bersamaan seorang pria hanya terkait dengan seorang wanita. Demikian pula sebaliknya, seorang wanita hanya terikat perkawinan dengan seorang pria pada saat yang bersamaan.

3) Sebagai suami isteri

Ikatan seorang pria dengan seorang wanita dapat dipandang sebagai suami isteri apabila ikatan mereka didasarkan pada suatu perkawinan yang sah. Sahnya suatu perkawinan diatur dalam Pasal 2 Undang-Undang Nomor 1 Tahun 1974 yang memuat dua ketentuan yang harus dipenuhi dalam pelaksanaan perkawinan. Pasal 2 ayat (1) Undang-Undang Nomor 1 Tahun 1974 menetukan bahwa perkawinan akan sah apabila dilakukan menurut hukum masing-masing agama dan kepercayaannya. Dalam penjelasannya dikatakan bahwa tidak ada perkawinan di luar hukum masingmasing agama dan kepercayaan dari para pihak yang akan melangsungkan perkawinan sesuai dengan Undang-Undang Dasar 1945.

Pasal 2 ayat (2) Undang-Undang Nomor 1 Tahun 1974 menyebutkan bahwa perkawinan dicatat menurut peraturan perundang-undangan yang berlaku. Sekalipun pencatatan bukan unsur yang menentukan keabsahan suatu perkawinan, tetapi pencatatan tersebut merupakan suatu keharusan sesuai dengan peraturan perundang-undangan yang berlaku. Pencatatan Perkawinan lebih lanjut diatur dalam Bab II Peraturan Pemerintah Nomor 9 Tahun 1975 tentang pelaksanaan Undang-Undang Nomor 1 tahun 1975 tentang Perkawinan.

4) Tujuan perkawinan adalah membentuk keluarga yang bahagia dan kekal.

Membentuk keluarga yang bahagia erat hubungannya dengan keturunan yang merupakan tujuan dari perkawinan, sedangkan pemeliharaan dan pendidikan anak-anak menjadi hak dan kewajiban orang tua. Agar dapat mencapai hal ini maka diharapkan kekekalan dalam perkawinan yaitu bahwa sekali orang melakukan perkawinan tidak akan ada perceraian untuk selamalamanya kecuali karena kematian.

5) Berdasarkan Ketuhanan Yang Maha Esa.

Undang-Undang Nomor 1 tahun 1974 memandang perkawinan berdasarkan asas kerohanian. Sebagai Negara yang berdasarkan Pancasila dimana sila pertama adalah Ketuhanan Yang Maha Esa, maka perkawinan mempunyai hubungan yang erat dengan 
agama/kerohanian sehingga perkawinan bukan hanya mempunyai unsur lahir/jasmani tetapi unsur rohani/batin juga mempunyai peranan penting.

Perkawinan yang sah menurut hukum akan menimbulkan akibat hukum sebagai berikut :

1) Timbulnya hubungan antara suami isteri;

2) Timbulnya harta benda dalam perkawinan;

3) Timbulnya hubungan antara orang tua dengan anak.

Akibat perkawinan terhadap suami isteri menimbulkan hak dan kewajiban antara suami isteri. Hak dan kewajiban antara suami dan isteri diatur dalam Pasal 30 sampai dengan Pasal 34 Undang-Undang Nomor 1 Tahun 1974, yang menetapkan sebagai berikut:

1) Suami isteri memikul kewajiban yang luhur untuk menegakkan rumah tangga yang menjadi sendi dasar susunan masyarakat;

2) Hak dan kedudukan isteri adalah seimbang dengan hak dan kedudukan suami dalam kehidupan rumah tangga dan dalam pergaulan masyarakat;

3) Suami isteri berhak melakukan perbuatan hukum;

4) Suami adalah kepala rumah tangga dan isteri ibu rumah tangga. disamping itu suami wajib memberikan segala sesuatu keperluan hidup rumah tangga sesuai kemampuannya dan isteri wajib mengatur rumah tangga sebaik-baiknya;

5) Suami isteri wajib saling cinta mencintai, hormat menghormati, setia menyetiai dan memberi bantuan lahir batin antara yang satu kepada yang lain;

6) Suami isteri harus mempunyai tempat kediaman yang tetap dan tempat kediaman tersebut ditentukan oleh suami isteri bersama.

Pada prinsipnya Perkawinan islam menganut asas monogami, namun dalam hal-hal tertentu dibolehkan berpoligami. Laki-laki boleh mempunyai maksimal empat orang isteri (Lihat Q.S. An-Nisaa ayat 129). Syarat utamanya adalah bisa berlaku adil diantara isteri-isterinya. Dalam Al-Qur'an Surat An-Nisaa ayat (129) Allah berfirman bahwa tidak seorang manusia pun yang dapat berlaku adil, karenanya kawinilah seorang wanita saja. Poligami hanya untuk keadaan darurat, agar terhindar dari dosa.

Untuk mengetahui asas-asas yang terkandung dalam UndangUndang perkawinan nasional ini, perlu memperhatikan Penjelasan Umum sub 3 Undang-Undang Nomor 1 Tahun 1974 yang intinya adalah : 
a) Undang-Undang Nomor 1 Tahun 1974 menampung di dalamnya unsur agama dan kepercayaan masing-masing anggota masyarakat yang bersangkutan.

b) Adanya asas equilibrium antara temporal dan kerohanian yang dapat disimpulkan dari tujuan perkawinan yaitu untuk membentuk keluarga yang kekal dan bahagia.

c) Dalam Undang-undang ini juga terdapat asas agar setiap perkawinan merupakan tindakan yang harus memenuhi syarat-syarat administrasi dengan jalan pencatatan pada catatan yang ditentukan Undang-Undang, artinya sebagai akta resmi yang termuat dalam daftar catatan Pemerintah.

d) Adanya asas monogami, akan tetapi tidak menutup kemungkinan untuk poligami jika agama yang bersangkutan mengizinkan untuk itu, namun untuk pelaksanaannya harus melalui beberapa ketentuan sebagai persyaratan yang diatur dalam Undang-Undang ini dan diputuskan oleh Pengadilan.

e) Adanya asas biologis yaitu perkawinan harus dilakukan oleh pribadi-pribadi yang telah matang jiwa raganya untuk dapat melangsungkan perkawinan agar dapat diwujudkan tujuan perkawinan secara baik tanpa berakhir pada perceraian dan mendapat keturunan yang baik dan sehat.

f) Kedudukan suami isteri dalam kehidupan keluarga adalah seimbang baik dalam kehidupan rumah tangga maupun dalam pergaulan kemasyarakatan, sehingga dengan demikian segala sesuatu dalam keluarga dapat dirundingkan dan diputuskan bersama oleh suami isteri.

Pada dasarnya UU No 1 tahun 1974 Perkawinan menganut asas monogami, meskipun tidak mutlak karena laki-laki boleh memiliki isteri lebih dari satu jika mendapat persetujuan dari pengadilan. Jika sebelumnya tidak ada persyaratan bagi suami untuk beristri lebih dari seorang, maka UU Perkawinan memberikan beberapa syarat yang harus dipenuhi sebelum suami berpoligami, diantaranya: isteri tidak dapat menjalankan kewajibannya, memiliki cacat badan atau penyakit yang tidak dapat disembuhkan, atau isteri tidak dapat memberikan keturunan. Selain itu poligami juga harus mendapatkan persetujuan dari isteri pertama. Syarat-syarat yang cukup ketat tersebut diharapkan dapat menekan angka poligami.

Pada kenyataannya, poligami yang dilakukan di luar persetujuan pengadilan masih terjadi. Menurut Nani Suwondo, sanksi yang diberikan bagi pelaku poligami tanpa izin pengadilan terlalu ringan, hanya berupa denda Rp. 7.500. Sebenarnya ada sanksi yang lebih berat sesuai dengan pasal 279 KUHP yang menetapkan ancaman hukum 
penjara 5 tahun bila seseorang menyembunyikan fakta bahwa perkawinan pertamanya bisa menjadi penghalang perkawinan kedua dan seterusnya. Hal ini didukung dengan adanya Surat Edaran Mahkamah Agung no MA/Pemb/0807/75 yang antara lain memuat: "Harus diingat pula bahwa mulai 1 Oktober 1975 pasal 279 KUHP berlaku pula bagi pria-pria Islam dan pria yang menganut agama atau kepercayaan yang memperbolehkan perkawinan poligami, yang mengambil isteri ke-2 dan seterusnya tanpa izin pengadilan menurut pasal 43 PP No. 9 tahun 1975. Nani Suwondo berpendapat bahwa pelaksanaan yang seksama terkait poligami akan mengurangi masalah kependudukan, memperbaiki kedudukan perempuan dan menjamin kesejahteraan keluarga (Nani Suwondo, 1984).

\section{CLD-KHI di Era Reformasi}

Setelah jatuhnya Orde Baru pergulatan hubungan agama dan Negara kembali menjadi wacana kenegaraan. Terbukanya ruang public yang bebas memberi peluang seluruh komponen bangsa termasuk umat Islam untuk mengekspresikan aspirasi, termasuk dalam bidang politik. Di tengah arus keterbukaan ini, Direktorat Pembinaan Badan Peradilan Agama (Ditbinbapera) membentuk Badan Pengkajian dan pengembangan Hukum Islam (BPPHI) tanggal 27 September 2002. Badan ini dibentuk untuk merealisasikan amanat UU no 25 tahun 200 tentang Prolegnas yang salah satu elemennya adalah penyusunan hukum substantif peradilan agama. Oleh karena itu pemerintah berusaha menaikkan status KHI dari Inpres menjadi UU. Maka dibentuklah tim CLD-KHI dibawah Pokja PUG Depag. Tim ini beranggotakan 11 orang yang 2 dintaranya adalah perempuan: Siti Musdah Mulia dan Anik Farida. Selain itu ada beberapa nama lain yang tidak tertulis secara resmi sebagai anggota tim, tetapi ikut berkontribusi dalam pembahasan CLD-KHI, yaitu: Badriyah Fayumi dan Lies Marcoes-Natsir (Wahid, 2014).

Dengan berdasarkan prinsip kesetaraan, keadilan dan kemaslahatan, maka tim CLD-KHI menyusun draft peraturan perkawinan yang menganut asas mongami. Dalam draft CLD-KHI, poligami dihukumi haram li ghairihi (dilarang mutlak karena sebabsebab yang lain). Oleh karena itu, segala peraturan yang berkaitan dengan poligami dalam KHI dihapuskan, kecuali pasal "asas perkawinan dalam Islam adalah monogami". Perdebatan terjadi sejak peluncuran naskah CLD-KHI tanggal 4 Oktober 2004 di Jakarta. ${ }^{1}$ Beberapa kalangan mendukung CLD-KHI tetapi banyak yang

${ }^{1}$ Ibid, hlm. 246

YUDISIA, Vol. 9 No. 2, Juli-Desember 2018 
Lina Kushidayati

menolaknya. Diantara para penentang adalah Huzaemah Tahido Yanggo yang menyusun buku Kontroversi Revisi Kompilasi Hukum Islam.

\section{Simpulan}

Sepanjang sejarah, perempuan Indonesia memiliki kontribusi di ruang public, termasuk dalam bidang hokum Perkawinan. Pembahasan tentang poligami menjadi salah satu itu yang muncul dalam diskusi dan penyusunan UU Perkawinan sejak masa sebelum kemerdekaan, hingga masa reformasi. Dalam perdebatan tentang poligami, perempuan tidak hanya menjadi pihak yang pasif, melainkan ikut memberikan kontribusi pemikiran baik secara individu maupun melalui organisasi. 
Perempuan Dan Isu Poligami Di Indonesia

\section{Daftar Pustaka}

Anderson, Benedict R. O'G. (Benedict Richard O'Gorman). 1991. Imagined Communities: Reflections on the Origin and Spread of Nationalism. Verso. http://library1.ga/_ads/EF571573265DE9384CE2CFED70EB51 CA.

Azizy, A Qodri. 2002. Eklektisisme Hukum Nasional. Yogyakarta: Gama Media.

Bedner, Adriaan, and Stijn Van Huis. 2010. "Plurality of Marriage Law and Marriage Registration for Muslims in Indonesia : A Plea for Pragmatism" 6 (2): 175-91.

Bennett, Linda Rae. 2005. Women, Islam and Modernity: Single Women, Sexuality and Reproductive Health in Contemporary Indonesia. London: RoutledgeCurzon.

Blackburn, Susan. 2004. Women and the State in Modern Indonesia. Cambridge: Cambridge University Press. https://doi.org/10.1017/CBO9780511492198.

Bowen, John R. 2003. Islam. Law and Equality: An Anthropology of Public Reasoning. Cambridge: Cambridge University Press.

Day, Tony. 2002. Fluid Iron: State Formation in Southeast Asia. University of Hawaii Press.

Hamdani, Suzana. 1984. "Riwayat Pertumbuhan Perkumpulan Istri Sedar." In Perjuangan Wanita Indonesia 10 Windu Setelah Kartini 1904-1984, edited by Departemen Penerangan RI. Departemen Penerangan RI.

Katz, June S ., and Ronald S . Katz. 2016. "The New Indonesian Marriage Law: A Mirror of Indonesia's Political, Cultural, and Legal Systems." American Society of Comparative Law 23 (4): 653-81.

Liddle, R. William. 1996. Leadership and Culture in Indonesian Politics. Sydney: Allen and Unwin.

Mangkusasmito, Rabingah Prawoto, and Sri Syamsiar Issom. 1984. "Peranan Wanita Islam Di Indonesia." In Perjuangan Wanita Indonesia 10 Windu Setelah Kartini 1904-1984, edited by Departemen Penerangan RI. Jakarta: Departemen Penerangan RI.

Martyn, Elizabeth. 2005. The Women's Movement in Post-Colonial Indonesia: Gender and Nation in a New Democracy. London \& New York: RoutledgeCurzon.

Mujiburrahman. 2006. "Feeling Threatened: Muslim-Christian Relations in Indonesia's New Order." Leiden University. 
Nani Suwondo. 1981. Kedudukan Wanita Indonesia Dalam Hukum Dan Masyarakat. Jakarta: Ghalia Indonesia. https://catalogue.nla.gov.au/Record/1641973.

. 1984. "Wanita Dan Masalah Pelaksanaan Undang-Undang Perkawinan." In Perjuangan Wanita Indonesia 10 Windu Setelah Kartini 1904-1984. Jakarta: Departemen Penerangan RI. Nurlaelawati, Euis. 2010. Modernization, Tradition and Indetity: The Kompilasi Hukum Islam and Legal Practice in the Indonesian Religious Court. Amsterdam: Amsterdam University Press.

Nurmila, Nina. 2009. Women, Islam and Everyday Life: Renegotiating Polygamy. New York: Routledge.

O'Shaughnessy, Kate Elizabeth. 2006. "Divorce, Gender, and State and Social Power: An Investigation of the Impact of the 1974 Indonesian Marriage Law." The University of Western Australia.

Panitia Peringatan 30 Tahun Kesatuan Pergerakan Wanita. 1958. Buku Peringatan 30 Tahun Kesatuan Pergerakan Wanita Indonesia, 22 Desember 1928-22 Desember 1958. Jakarta: Percetakan Negara.

Pranoto, Suhartono W. 1994. Sejarah Pergerakan Nasional : Dari Budi Utomo Sampai Proklamasi, 1908-1945. Pustaka Pelajar. https://catalog.hathitrust.org/Record/002907654.

Proyek Penelitian dan Pencatatan Kebudayaan Daerah. 1977. Sejarah Kebangkitan Nasional Daerah Istimewa Yogyakarta. Jakarta: Departemen Pendidikan dan Kebudayaan, Pusat Penelitian Sejarah dan Budaya. https://catalogue.nla.gov.au/Record/1468501.

Rasjidi, Lili. 1991. Hukum Perkawinan Dan Hukum Perceraian Di Malaysia Dan Indonesia. Bandung: PT Remaja Rosdakarya.

Sosroatmodjo, Asro, and A. Wasit Aulawi. 1978. Hukum Perkawinan Di Indonesia. Jakarta: Bulan Bintang.

Susan Blackburn. 1991. "How Gender Is Neglected in Southeast Asian Politics." In Why Gender Matters in Southeast Asian Politics, edited by Maila Stivens. Monash: Centre for Southeast Asian Studies: Monash University.

Wahid, Marzuki. 2014. Fiqh Indonesia: Kompilasi Hukum Islam Dan Counter Legal Draft Kompilasi Hukum Islam Dalam Bingkai Politik Hukum Indonesia. Bandung: Penerbit Marja. 
273 